\title{
Textens grænser
}

Den strukturalistisk-semiologiske analyse bestemmer sit emne som den objektiverede text. Således hos Greimas: "Tout discours présuppose, on le sait, une situation non linguistique de communication. Cette situation est recourverte par un certain nombre de catégories morphologiques, qui l'explicitent linguistiquement, mais en introduisant en même temps dans la manifestation un paramètre de subjectivité, nonpertinent pour la discription et qu'il faut par conséquent éliminer de texte." (Sémantique Structurale, s. 153).

("Enhver discours ("discours" er en term, hvis oversættelse ikke generelt kan fastholdes. Inden for rammerne af Semantique Structurale kan "sproganvendelse" med rimelighed benyttes) forudsætter, vil man vide, en ikke-lingvistisk kommunikationssituation. Denne situation dækkes af et bestemt antal morfologiske kategorier, som ekspliciterer den i lingvistisk henseende, men som på samme tid i manifestationen indfører et "subjektivitetsparameter", der ikke er pertinent for beskrivelsen, og som det derfor er nødvendigt at fjerne fra texten).

Som eksempler på elementer fra det subjektive parameter, der måtte true textens objektive status, nævnes: 1) alle personaspekter med undtagelse af 3 . person 2) alle tidsformer med undtagelse af fortalt tid 3) alle stedsangivelser der ikke er textimmanente 4) alle fatiske elementer. Disse fire punkter er tilstrækkelige til at vise, at den objektiverede text forudsætter en abstraherende bestemmelse, der løsriver texten fra dens konkrete og specifikke betingelser.

Texten fremtræder således som en færdighed, et produkt, et emne for den afsluttende og udtømmende beskrivelse. Men objektiveringen bliver hermed samtidig textens indskrivning i mysteriet, texten fremtræder som en åbenbaring $\mathrm{i}$ tomheden. Textens produktion, dens forudsætninger som produkt, flyttes fra samfundsmæssige, intertextuelle forhold til beskrivelsen, der ved at afgrænse og fastholde texten bliver dennes egentlige grund. Beskrivelsen, læsningen, konsumtionen bliver textens univers, en suveræn og vilkårlig dynamik, og den forventelige modsigelse udebliver således ikke: stik imod prætentionen om objektivitet bliver texten et udtryk for fad subjektiv idealisme.

Textens nødvendighed må $\mathrm{i}$ denne sammenhæng fremstilles som en immanent lovmæssighed, hvis grænser sættes af meningen som suveræn autonomi. Beskrivelsens konstituering af meningen som lov sætter den 


\section{0}

kohærens, der etablerer textobjektet ved at afgrænse texten fra det meningsløse eller ulovlige.

Den strukturalistiske textmodel er da en stratifieret reduktiv model, der bestemmer de enkelte specificerede betydningsstrata på textens logiske niveau. Men netop reduktionen volder problemer: de enkelte textobjekter karakteriseres ikke blot internt men også i deres indbyrdes relationer ved redundans, og $\mathrm{i}$ stedet for textuniversets specifikke mangfoldighed udmunder beskrivelsen i meningens logisk-isotope konstans, betydningsproduktionen bliver en opremsning, beskrivelsen en fortvivlet-triumferende konstatering, textens grænse meningens grænseløse redundans. Dette er muligheden: at fastholde textens "stilistiske" særpræg eller ceremonielt henvise til meningens permanens.

I den udstrækning den strukturalistiske textteori er en adækvat udformning af en udbredt bevidsthedsform, vil en analyse på strukturalismens principper være en explicitering og en etablering af denne bevidsthedsform som betydningsstruktur, og vil dermed være en overskridelse af denne bevidsthedsforms grænser $i$ henseende til praxis. Denne informative funktion giver strategisk den strukturalistiske analyse sin berettigelse. Men skal denne overskridelse videreføres i psykoanalysens forstand, er det et spørgsmål, hvorvidt den strukturalistiske model ved sin blotte explicitering og dermed fastholdes af denne selvforståelses kohærens er en anvendelig model.

Spørgsmålet må stilles, hvorledes den strukturalistiske textmodel (kan) integreres $i$ en semiotisk teori. Den semiotiske teori er bl.a. bestemt $i$ forhold til den strukturalistiske ved at "indsætte" texten i dens produktive dialektik. Men netop metaforen angiver problemet: hvad der kan indsættes, er texten som lov og fornuft, og den semiotiske indsats er, fornuftigt og lovmæssigt, at forklare texten som ufornuft. Således sætter den semiotiske praxis textens sekundære grænse ved generelt, optativt at etablere sig i en kohærent dialektik. Angivelsen af strukturens modsætninger er kun en overskridelse af enheden for så vidt denne forstås som identitet, modsætningen fastholdes samtidig i en logisk kontinuitet (fx hos Derrida, hvor kontinuiteten er en forudsætning for sảvel differance som trace). Den fragmentariske eller heterogene betydning er for den semiotiske analyse et endnu ikke, analysens første trin. Den videre analyse opretter konsistensen som modsætning til den falske bevidsthed eller ideologi og indlejrer partikulariteten heri. Analysens fire faser: manifest/ immanent/ideologisk-textuelt/materielt-produktivt/ svarer således til: partikulært-kohærent/partikulært-fragmentarisk/generelt-fragmentarisk/generelt-kohærent/.

Sáledes transformerer semiotikken den partikulært-kohærente løgn til den generelt-kohærente sandhed, og hvor flertydigheden og forskydningen truer gribes til den freudianske håndspålæggelse. 
Den freudianske teori er bestemt ved sin flertydighed, og allerede i Traumdeutung viser dobbeltheden sig. Drømmearbejdet fremstilles sine steder som en i princippet redundant proces: "Drømmetanker og drømmeindhold står for os som to fremstillinger af det samme indhold på to forskellige sprog, eller bedre udtrykt: drømmeindholdet forekommer os at være en overføring af drømmetankerne til en anden udtryksmåde, hvis bogstaver og grammatik vi skal lære at kende ved en sammenligning mellem original og oversættelse" ("Drommetydning" H. Reizel, 1960). "Original og oversættelse", "samme indhold", "to forskellige sprog" etc. er fremstillinger af "meningen" som en etableret, essentiel struktur, og drømmearbejdets eneste funktion er i denne sammenhæng at manifestere denne mening så cencurinstansen omgås. Således: "drømmetankerne er uden videre forstảelige for os, så snart vi har lært dem at kende".

Det udvendighedsforhold drømmearbejdet her sættes i, svarer til Althussers fremstilling af den empiristiske teori:

"L'abstraction empiriste, qui extrait de l'objet réel donné son essence, est une abstraction réelle, qui met le sujet en possession de l'essence réelle. On va voir que la répétition, à chacun des moments du processus, de la catégorie de réel est distinctive de la conception empiriste. Que signifie en effet une abstraction réelle. Elle rend compte de ce qui est déclaré un fait réel: L'essence est abstraite des objets réels au sens réel d'une abstraction, comme on peut dire que l'or est extrait (ou abstrait, donc separé) de la gangue de terre et de sable dans laquelle il est pris et contenu. De meme que l'or avant son extraction, existe comme or non séparé de sa gangue dans sa gangue meme, de meme l'essence du réel existe, comme essence réelle, dans le réel qui la contient. La connaissance est abstraction, au sens propre, c'est-à-lire extraction de l'essence du réel qui la contient, seperation de l'essence du réel qui la contient et la recele en la cachant". (Lire le Capital, p. 39/40).

("Den empiristiske abstraktion som abstraherer det virkelige objekts essens, er en egentlig abstraktion, som sætter subjektet $i$ besiddelse af den reelle essens. Man vil se at gentagelsen, ved hvert af fremgangsmådens momenter, af det reelles kategori er et afgørende træk i empirismens konception. Hvad betyder en reel abstraktion i virkeligheden. Den redegør for det der hæudes som en reel kendsgerning: essensen abstraheres fra det virkelige objekt $\mathrm{i}$ abstraktionens egentlige forstand, som man kan sige at guldet extraheres (eller abstraheres, altså adskilles) fra jordmassen og sandet $\mathrm{i}$ hvilket det er optaget og indeholdt. På samme måde som guldet før extrationen eksisterer som adskilt eller ikke fra jordmassen $i$ selve denne masse, eksisterer den reelle essens, som reel essens, i den virkelighed som rummer den. Erkendelsen er abstraktion i egentlig forstand, d.v.s. abstraktion af essensen fra den virkelighed som indeholder den, adskillelse 
212

af essensen fra den virkelighed som ved at skjule den indeholder og tilbageholder den.").

Denne "althussersk" - empiristiske textmodel fastlægger betydningsessensen negativet, men dette er kun første led i kohærensens oprettelse, betydningens textualitet er ikke direkte impliceret af forskellen. Men igen er det muligt allerede $\mathrm{i}$ Traumdeutung at finde formuleringer, der anfægter denne kohærens, og dermed problematiserer en henvisning til den freudianske teori som det forklaringsprincip, der skal garantere kohærensen. Således må Freud konstatere at "Fortætningskvotienten er altså strengt taget - ubestemmelig", idet det altid er muligt "at endnu en mening giver sig til kende i samme drøm". Jeg vælger her, i forlængelse af Althusser, at læse i "streng forstand". Det specificeres ikke på hvilket niveau denne anden mening kan tænkes, og flertydighedens strukturelle karakter specificeres heller ikke, men fortætningskvotientens ubestemmelighed gøres gældende generelt, og dette er en afgørende åbning i den freudianske teori, der muliggør en splintring af de betydningskonstituerende faktorer.

I analysen af drømmen om den botaniske monografi fremstilles fortætningsarbejdet endvidere $i$ en metaforik, der understøtter denne åbning. Fortætningselementerne omtales som "fællesnævner" og "knudepunkter", og dette harmonerer ikke helt med forestillingen om fortætningen som en komprimeret indlejring. Indlejringsteorien svarer til drømmetankernes strukturelle sammenfald i drømmeindholdets enkelte elementer (som en isotop reduktion), hvorimod de to næunte metaforer nok forudsætter en kontiguitet, men denne oprettes på drømmetankernes særligt indifferente elementer. I stedet for at forklare dette ved en henvisning til censuren, kunne man forsøgsvis se det som et udtryk for drømmetankernes inkohærens og uforenelighed.

I denne forbindelse kan overdeterminationen forstås ikke blot som den for drømmearbejdet specifikke fremstillingsform, koncentrationen, men som selve den kohærensetablerende instans. Ved at anvende overdeterminationsbegrebet således som Althusser har udformet det, vil drømmearbejdet kunne forstås som en treleddet proces. 'Denne afspejling af modsætningens eksistensbetingelser indenfor sig selv, denne afspejling $i$ den artikulerede dominantstruktur, der udgør enheden i den komplekse helhed i hver modsætning, er den marxistiske dialektiks dybeste træk, det jeg for nylig forsøgte at få hold på med begrebet overdetermination" ("For Marx" Rhodos 1969). Dette afspejlingsforhold er, som det fremgår af citatet, den totalitetsetablerende relation og det karakteristiske er, at relationen ikke fixeres $i$ et lineært determinationsforhold, men bestemmes som en flerdimensional relation (relativ autonomi), hvilket igen fører til Althussers pointe om den altid allerede givne komplekst strukturerede helhed. Sammenholdes Althussers dialektik med Freuds overdetermination, sådan 
som jeg her har forsøgt at læse den, vil man få mulighed for at fremstille en dialektisk model, hvori betydningshelheden (kontinuiteten, konsistensen etc.) ikke betegner strukturens totalitet, men et område.

Man må her tænke betydningsarbejdet struktureret på tre instanser: den specifikke text ("drømmen"), en betydningsmæssig intertextualitet, et fragmentarisk diskrepant betydningsunivers. Overdeterminationen er da det arbejde, der konstituerer kohærensen ved i produktionen at sammenføre den givne kohærens (intertextualiteten) med den fragmentariske betydning i den specifikke text. Denne strukturelle dannelse vil samtidig være et indgreb $\mathrm{i}$ intertextualiteten, hvilket igen vil kunne resultere $\mathrm{i}$ en partikulær fragmentering. I henseende til en bestemt læsning af Freud's drømmemodel er denne skitserede model karakteristisk ved at vende forholdet mellem drømmeindhold og drømmetanker, idet drømmetexten her fremtræder som det sted hvor helheden konstitueres (sml. i øvrigt drømmens sekundære bearbejdning), intertextualiteten som det sted hvor betydningen fragmenteres.

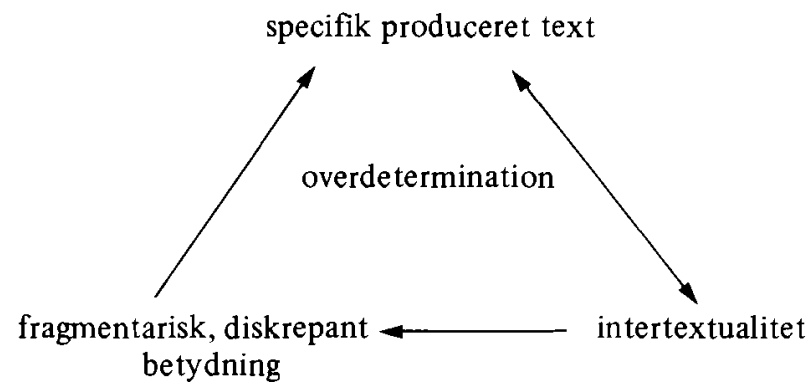

Denne produktionsproces er her fremstillet helt abstrakt og skal placeres i sine materielt determinerende relationer. Det konkrete teoretiske problem vil være at angive fragmenteringens plads i betydningsproduktionen, hvor denne anskues som en partikulær dominantstruktur i relativ autonomi.

En sådan præcisering kan indledningsvis søges $i$ en beskrivelse af det klassiske textmateriale, der netop karakteriseres ved en tilsyneladende etableret kohærens. Man skal dog ikke vente her at finde den bedste anledning til at konkretisere fragmentationens tematik, idet den klassiske texts strategi tager sigte på ikke blot at afgrænse denne betydningsform, men direkte at udskrive den. Muligheden vil altså være at bestemme denne texts kohærensprincipper, deres relationer til en intertextualitet samt om muligt at angive denne textualitets sammenbrud.

Det er næppe nogen overdrivelse at hævde, at den strukturalistiske textmodel er udarbejdet til beskrivelse af et klassisk textunivers, jvf. 
narratologien, tematikken og den strukturelle semantik. Sigtet med beskrivelsen har været at give en formaliseret, generel fremstilling af texterne inden for betydningsgrænser der svarede til en traditionel læsning og forståelse af betydningsuniverset. Disse grænser markeredes af begreber som mening, specificitet, enhed individ etc. Denne models strukturelle fixering på to textniveauer, det logisk-isotope og det antropomorfe, harmonerer med denne intention. Således ækvivalerer det logiske niveau med et paradigme hvori bl.a. indgår termerne mening og enhed, det antropomorfe niveau med paradigmet individ, specificitet osv.

Denne strukturelle model fremstiller først det antropomorfe niveau som en række handlingsbestemte transformationer, centreret omkring et individ (helt, hovedperson). Forløbet er et udtryk for dette individs vilje og intentioner, og den textuelle dialektik er på dette niveau et resultat af konfrontationen mellem de individuelle kvalifikationer og funktioner og en ikke-individuel struktur (kollektiv, nartur, skæbne). Men i og med at betydningen afspejles fuldstændig i dette individ fremstår strukturen som en specificitet, udformet af individets praxis. Specificiteten transformeres dernæst på det logiske niveau til et generelt fænomen, idet betydningens samlende faktor ikke her er et individ, men derimod betydningens generelle sammenhæng og fornuft, meningen. Det antropomorfe niveau er derfor denne overordnede strukturs fremstilling $i$ en særform, den historisk-særegne begivenhed som manifesterer og demonstrerer meningen. Textens gyldighed eller sandhed er identisk med denne mening, og i den strukturelle models abstraktion konstitueres den som en logisk nødvendighed, en nødvendig sammenhæng mellem betydningselementer. Texten beviser sin uafviselighed ved generelle betydningers systematisk-transformative sammenhæng, og bevistets forløb placeres $\mathrm{i}$ læsningen (den bevidste) hvor denne gyldighed erkendes igennem og bag historiens fluktuation. Texten har således lukningen som forudsætning, en lukning der indbefatter den sande menings pertinens, men som udelukker den textuelle produktion, modsætningen, heterogeniteten, d.v.s. intertextualiteten og fragmentationen.

Men således som drømmeproduktionens forhold kunne vendes ved en påpegning af en tredje betydningsform, kan textens bevisførelse vendes og i forhold til det logiske niveau henføres til det antropomorfe. I stedet for at være meningens demonstration fungerer dette betydningsniveau da som den dialektik der konstituerer meningens mulighed, "beviset". Den særlige kohærens som etableres her, vedrører den menneskelige handlen som kvalitativ transformerende praxis, og beviset tilvejebringes ved, at den mening, de enkelte handlinger bærer, struktureres som en værdiintegrerende praxismodel. Meningen er gyldig fordi den er en angivelse af den værdifulde handlen.

Denne bestemmelse af det antropomorfe niveau accentuerer 
spørgsmålet om individkategoriens status i texten, eftersom det er i den traditionelle handlingssfære, dialektikken placeres. Dette kræver en nærmere præcisering af forholdet mellem individ- og aktantbegrebet. Den vasentligste forskel mellem disse to begreber er, at hvor individet (aktøren) er den betydningskonstituerende størrelse på det antropomorfe niveau, hvori betydningen strukturelt indlejres, er aktanten en kategori af reducerede invariable prædikative elementer. Det kunne derfor se ud som om aktanten var en vasentlig gevinst i det teoretiske arbejde på at udarbejde et subjektbegreb, som kunne udfylde pladsen som konstituerende-konstitueret element $i$ en dominantstruktur. Men til dette formål er aktantmodellen ikke synderlig mere egnet end individtermen, idet de begge som karakteristik har betydningens enhedsmæssige form som overordnet bestemmelse. Forskellen er blot, at individtermen som figurativ form abstrakt forudsætter denne enhed. Det reduktive forhold mellem de to elementer er i ovrigt helt identisk med en strukturalistisk niveaumodel (sml. fx Propp's bestemmelse af reduktionen mellem handling og funktion).

Arbejdet på et subjektbegreb vil derfor løbe parallelt på de to niveauer, og subjektet vil her være den term som det overdeterminerede transformationsarbejde $i$ en given praxis kan tilskrives. I denne forbindelse er drømmeaktørens funktion oplysende. Således i forbindelse med "Irmadrømmen": "Ingen af disse personer, som jeg støder på ved at følge efter "Irma", optræder legemligt i drømmen; de skjuler sig bag drømmepersonen "Irma", der på denne måde formes til et kollektivbillede med, må det indrømmes, en række modstridende træk. Irma bliver til repræsentant for disse andre, ved fortætningsarbejdet of rede personer, idet jeg punkt for punkt overgiver alt det, der minder om disse personer, til hende" ("Drømmetydning"). Som subjekter permuteres aktørerne altså indbyrdes efter de principper der i øvrigt angives for overdeterminationen, d.v.s. den adækvate spejling. Derfor tilskrives prædikaterne ikke subjektet, men indikeres af dette, subjektet påpeger overdeterminationens plads (overdetermination i Althusser's forstand). Subjektets funktion kan bestemmes som en grammatisk overordnet demonstrativ term, der angiver en given praxis' textuelle sted. Subjektet er ikke som overordnet reduktiv kategori bærer af eller identisk med betydningen, men aftegner dennes geografi. På denne måde er de enkelte subjekter lige så mange mærkninger af helheden, og forskellen mellem aktør og aktant svarer til forskellige helhedsspecifikationer. Et subjektbegreb udarbejdet efter disse retningslinier vil konstituere et formalt textbegreb.

Strukturen på det logisk-isotope niveau tænkes konstrueret på to hovedforhold: for det første må den handlingsmæssige sammenhæng formuleres som en lovmæssighed, således at loven semiotisk fungerer som praxis generelle forskrifter, for det andet mả betydningen differeres $i$ en 
bestemt værdimæssig struktur. Endelig mả selve transformationen defineres som relationen mellem disse to forhold. En sådan betydningsmodel kan findes i Greimas' formalisering af Propp's funktionsrække. Loven fremstilles her som en kontrakt (termens bevidsthedsimplikation er en reminiscens fra Propp's funktioner, men refererer samtidig netop til det antropomorfe niveaus subjektivt-figurative fremstilling, hvor loven defineres som en gensidig afhængighed mellem et individ og et kollektiv), der kan antage en såvel positiv som negativ form, som kontraktetablering og -brud. Kontraktetableringen udtrýkker lovens samfundsmæssige eller kollektive form, kontraktbruddet kollektivitetens negation, og omvendt manifesterer kontraktetableringen individtermens negation, kontraktbruddet dens affirmation. To kontraktformer svarer derfor til to lovmæssigheder i et modsætningsforhold, et resultat af handlingens antagonistiske karakter på det antropomorfe niveau. De to lovforhold vises dernæst at implicere forskellige værdisystemer. Beskrivelsen af værdisystemerne rummer imidlertid en del uklarheder hos Greimas. Greimas betegner værdirelationen som C vs $\bar{C}$ ("C" står for communikation) og bestemmer $\overline{\mathrm{C}}$ som værditab i modsætning til værdibesiddelsen $C$. Transformationsmodellen $A \rightarrow C$ vs $\bar{A} \rightarrow$ $\overline{\mathrm{C}}$ (hvor A betegner lovstrukturen) bliver da noget gådefuld, idet det er svært at se hvorledes en handling svarende til den anden implikation begrundes. Forholdet er da også komplekst, således at der til hver af kontraktformerne svarer hhv. en værdibesiddelse og et værditab. Hver fase $i$ transformationen er endvidere et udtryk for den kollektive og den individuelle lovs gensidige forhold, og den greimasianske transformationsmodel kan derfor omformuleres således:

$$
\overline{\mathrm{L}} \quad\left\{\begin{array}{l}
\mathrm{A} \rightarrow\left(\overline{\mathrm{C}}_{1}+\mathrm{C}_{2}\right) \\
\overline{\mathrm{A}} \rightarrow\left(\mathrm{C}_{1}+\overline{\mathrm{C}}_{2}\right)
\end{array}\right\} \overline{\mathrm{V}} \longrightarrow \mathrm{L} \quad\left\{\mathrm{A}_{\mathrm{o}} \rightarrow \mathrm{C}_{\mathrm{o}}\right\} \mathrm{V}
$$

hvor $\mathrm{L}$ står for relationen mellem $\mathrm{A}$ og $\overline{\mathrm{A}}, \mathrm{og} \mathrm{V}$ for relationen mellem $\mathrm{C}$ og $\bar{C}$. Når A og C termerne i sidste klamme mærkes med et "o" udtrykkes der dermed, at udformningen af termerne i denne slutfase i transformationen er den enkelte texts specifikke bidrag til betydningsproduktionen. Som udbredte eksempler på sådanne "løsninger" kan nævnes mediationen eller fortrængningen af den ene implikation. Forudsætningen for den sidste mulighed (som er den Greimas opererer med) er, at den bevarede værdiimplikations positive term øges væsentligt, eller dens negative term formindskes tilsvarende. (Man må forudse endnu en omstrukturerin af modellen, hvor L-V implikationen bestemmes ud fra et konsekvent udvekslingsmæssigt synspunkt). Den væsentlige fortjeneste ved Greimas' model er imidlertid, at transformationen ikke fremstilles som et simpelt 
AC forløb, men at etableringen af den positive lov forudsætter værdibesiddelsen. Således: $(\overline{\mathrm{A}} \rightarrow \overline{\mathrm{C}}) \rightarrow(\mathrm{C} \rightarrow \mathrm{A})$. En sammenligning af Greimas' og Propp's modeller vil endvidere vise, at transformationen ikke afsluttes af kontraktetableringen. Greimas har tilsyneladende ikke øje for det værdimæssige aspekt i Propp's afsluttende funktion W, som betegner brylluppet, idet han ser helt bort fra besiddelsen af prinsessen og identificerer funktionen med den kollektive norms oprettelse. Denne normetablering finder imidlertid sted på et tidligere tidspunkt (ved den kollektive anerkendelse af helten som helt og dermed det lovsystem han modalt repræsenterer) og W-funktionens væsnetligste betydning bliver da værdiintegrationen. Herefter ser forløbet således ud: $(\bar{A} \rightarrow \bar{C}) \rightarrow(C) \rightarrow(A \rightarrow C)$. En analyse af det textmateriale modellen er en generalisering af, vil samtidig vise (jeg vil her nøjes med at henvise til min analyse af eventyrets semiotik, som vil udkomme i "Textstrukturer"), at den værdietablering, som er den positive transformations forudsætning, svarer til det område i textens økonomi hvor produktionen finder sted (jvf. at dette sted (F) af Greimas bestemmes som forløbets irreducible diakrone kerne). Omvendt kan der for kontraktbruddet forudsættes en produktionsnegation. Bestemmes LV-parantesen så som økonomiens udvekslingsmæssige område (hvilket som nævnt blot forudsætter at loven ses som en kommunikation, og det kan næppe være nogen ophidsende påstand) vil modellen tage sig således ud:

$$
(\mathrm{L} \rightarrow \mathrm{V}) \rightarrow \overline{\mathrm{V}}_{\mathrm{o}} \rightarrow(\overline{\mathrm{L}} \rightarrow \overline{\mathrm{V}}) \rightarrow \mathrm{V}_{\mathrm{o}} \rightarrow(\mathrm{L} \rightarrow \mathrm{V})
$$

hvor $\mathrm{V}_{\mathrm{o}}$ betegner værdiproduktionen. Denne model kan endelig placeres $\mathrm{i}$ den såkaldte betydningens grundstruktur:

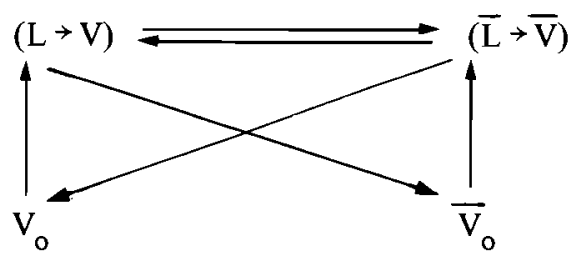

Der er måske grund til at understrege, at implikationen mellem $\mathrm{L}$ og $\mathrm{V}$ ikke er automatisk, men i hvert tilfælde kræver et specifikt textuelt arbejde. Man kan derfor for fuldstændighedens skyld skrive

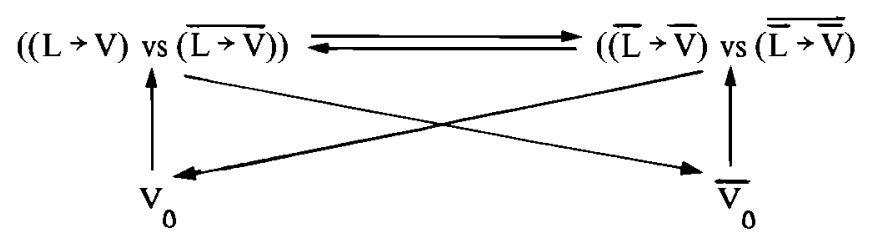


Den greimasianske textmodel kan integreres i en mere omfattende model, som vil vare et forsøg på at fremstille den klassiske texts konstituerende træk. I denne model fastholdes operativt den strukturalistiske skelnen mellem et antropomorft og et logisk niveau, og dette fordrer i forlængelse af den tidligere diskussion en nærmere bestemmelse af det første niveaus grundlæggende elementer, det antropomorfes prædikater. Disse vil være de kvalifikative kategorier etableret på sidste trin af reduktionen af prædikaterne knyttet til en given texts aktører, således at den derved fremkomne isotopi differerer textuniversets "menneskelige" betydningsfære. En sådan bestemmelse beror på en kontre = semiotisk analyse, idet de antropomorfe prædikater ikke tænkes i en abstrakt filosofisk sammenhæng, men konkret specificeres og generaliseres af den enkelte texts indgreb i betydningsdialektikken. Man kan i Derrida's analyser finde et udgangspunkt for en sådan analyse, idet bevidsthedskategorien her synes at etablere antropomorfismens tematik, intentionen at betegne bevidsthedens transformation mod en handlen ( $i$ øvigt kan man bemærke at forholdet mellem "bevidsthed" og "bevidsthedsindhold" rejser de samme problemer som forholdet mellem subjekt og prædikat). Textens integration af antropomorfismens prædikater som differentielt træk sættes som første bestemmelse af den søgte textmodel. Dernæst forudsættes det, at de antropomorfe prædikater investeres $\mathrm{i}$ en transformation, der som basis har en axiologisk bestemt implikation mellem lov og værdi som i den greimasianske model (herunder lovens modsætningsstruktur og værdistrukturens kompleksitet). Endelig skal transformationen intentionelt være rettet mod etableringen af en enhedsmæssig, generel implikation. Denne textmodels emne kan benævnes MYTEN (som myteeksempler kan nævnes "marxismen" og "freudianismen". Ikke transformative texter kan forstås som partielle fremstillinger af myten). Mytemodellen vil i bredt omfang angive rammer for den kohærente, kontinuære text og vil således være en forudsætning for formuleringen af fragmentationens, partikularitetens, heterogenitetens etc. problematik.

\section{Et kort analyseeksempel. Orneflugt}

Den mytologiske beskrivelse af ørneflugt tager sit udgangspunkt i textens klart disjunktive univers, tematiseret i forholdet mellem præstegárden og ørneriget som en natur-kulturmyte. A-kategorien funderes kulturelt som forholdet mellem Klavs og Præsten (eller præstens repræsentanter). Således om Klavs: "Den vraltede som sædvanlig omkring mellem de andre husfugle, altid fredsommelig, næsten lidt ængstelig, fordi den var vant til at få over næbet af præstedøtrene, når den engang imellem fandt på at gøre sin medfødte overlegenhed gældende overfor Smaakravlet". Lovforholdet svarer her til en etableret dominansrelation, hvor det enkelte subjekts 
kvalifikationer negeres i den kollektive struktur. Loven opretholdes og effektueres af myndighedens højeste repræsentant, præsten, og loven formidles som et nøje fastlagt hierarki, der restløst definerer det enkelte individs muligheder og rettigheder. Lovstrukturen svarer således i dette tilfælde til den extreme udformning af individuel-kollektiv problematikken som Greimas fremstiller, idet denne lovstrukturs komplexitet snarere er et teoretisk end et praxisfænomen, individstrukturen er helt fortrængt. C-kategoriens komplexitet er derimod manifest, og hvert af værdisystemerne $k$ an specificeres efter to forskellige paradigmer, svarende til hhv. simple og komplekse termer. Den positive værdikategoris simple termer artikuleres primært i en ernæringsisotopi: fyldt fad/dampende fad/smảgrisene med pattevorten i munden/ . . formelig lagde sig mave til. Hertil kommer så de komplekse termers paradigmer, der bestemmes efter aksen exteroceptivt vs interoceptivt. Til disse paradigmer hører termerne varme vs kulde/goldhed vs frodighed/ renhed vs urenhed. (De komplekse termer vil fx kunne fremstilles som $\mathrm{i}$ det følgende skema, men det kræver en analyse som overskrider rammerne for dette analyseeksempel, jeg medtager det kun for overskuelighedens skyld:

\begin{tabular}{lllll} 
& \multicolumn{2}{c}{ interaceptivt } & \multicolumn{2}{c}{ exteraceptivt } \\
& euforisk & dysforisk & eurorisk & dysforisk \\
\cline { 2 - 4 } kultur: & kulde & varme & varme & kulde \\
natur: & varme & kulde & kulde & varme).
\end{tabular}

Kulturimplikationen negeres ved præstens død, d.v.s. ved frafaldet af den lovkonstituerende aktør, jvf. Propp's første funktion. Lovens negation er således naturliggjort som død, hvorved texten abstraherer fra den værdiproduktionens problematik som den mytiske dialektik demonstrerede. Naturuniversets lovmæssighed svarer til affirmationen af den individuelle kategori, d.v.s. Klavs' suverænitet ved manifestationen af de individuelle prædikater: "Den følte med eet, at den var Ørn". De implicerede positive værditermer sættes generelt i modsætning til kulturen som en euforisk rus, funderet $\mathrm{i}$ den individuelle, ubegrænsede udfoldelse: 'hvorpå den pludselig med et vildt frydeskrig svang sig i en stor bue højt op i luften" og "beruset af den vide horisont" (begrænsningstermerne er metaforiske udformninger af lovforholdet, der her negeres). Denne euforiens ekspansion forstås når termerne subsumeres under en sexualitetens isotopi, manifesteret i mødet med hunørnen. Men det er nu bemærkelsesværdigt, at værdiimplikationens negative termer manifest ekspanderer, for tilsidst at udskyde den positive axiologi. Dette forklares 


\section{0}

ved Klavs' angst for og ukendskab til ørneriget: Skrækslagen/Rystende af kulde og uhygge/dette hvide dødningeland/stjerner ligesom onde katteøjne; begrundelsen skal i denne sammenhæng søges i ørnens opvækst i andegården-præstegården, der kulturelt sætter en negation af de individuelle prædikater og dermed umuliggør transgressionen.

Dette svarer vist nogenlunde til den traditionelle læsning af "Ørneflugt" og kan som myte forstås som følger: den generelle implikation mellem lov og værdi differerer betydningsuniverset $\mathrm{i}$ to disjunkte områder med hvert sit A-C forhold (som fx. ænderne og hunørnen). Disjunktionen er både en forudsætning og en garanti for værdiintegrationen, derimod fører en konjunktion til en uoprettelig A-C negation, lovens overtrædelse og værditabet:

$$
\begin{aligned}
& (L \rightarrow V):\left(\left(A_{1} \rightarrow C_{1}\right) \underline{v}\left(A_{2} \rightarrow C_{2}\right)\right) \\
& (\bar{L} \rightarrow \bar{V}):\left(\left(A_{1} \rightarrow C_{1}\right) \wedge\left(A_{2} \rightarrow C_{2}\right)\right) \rightarrow\left(\bar{A}_{o} \rightarrow \bar{C}_{o}\right)
\end{aligned}
$$

hvor mytenegationen svarer til handlingsforløbet og dermed til $(\mathrm{L} \rightarrow \mathrm{V})$ 's affirmation. Myten er således ikke transformativ i dette tilfælde, d.v.s. at anden del af mytedialektikken ikke findes i handlingsforløbet. Men texten er ikke desto mindre mytisk ved at anvise den værdiintegrerende praxis inden for et lovmæssigt differeret betydningsunivers. Bevisførelsen er i dette tilfælde negativ i overensstemmelse med strukturens statiske karakter: strukturens nødvendighed erkendes ved transgressionens umulighed.

En videregående analyse af ornerigets kvalifikative paradigmer vil imidlertid vise, at lukningen og dermed textens "fornuft" kun er tilsyneladende. Klavs' fjerdragt beskrives som smudsig, hvilket står i modsætning til ørneriget, som er ubesmudset af de levendes færden. Læses oppositionen urenhed vs renhed ud fra de komplekse termers paradigme, vil det ses, at naturen karakteriseres ved en interoceptiv, dysforisk urenhed. Renhedsmetaforikken skal i øvrigt ses i sammenhæng med koblingen af renheden, hvidheden og uberørtheden, det sidste vil efter handlingsforløbet sige: urørligheden. Denne naturens urenhed er det, den følgende analyse bl.a. vil søge at belyse.

Da Klavs standser ved orneriget differer han grænsen mellem natur og kultur, men peger samtidig på bevægelsens mulige fortsættelse, en fortsættelse som texten fremstiller ved at tematisere stjernerne som universets yderste truende mærkninger før grænseløsheden. For at forstå grænsens problematik må overskridelsens mulighed sættes i forbindelse med, at ørneriget bestemmes ved kvalifikationerne overjordisk og evig, og derfor foruden at pege på transgressionen henviser til en transcendentalitet, d.v.s. en negation der som fundamental forskel truer det mytiske univers' natur/kultur differens. Natur-kultur tematikken kan nu etablere tre textuniverser: et univers bestemt af den naturlige kultur eller den 
kulturelle natur, et textunivers svarende til den ikke-medierede natur og endelig et univers svarende til den ikke medierede kultur. Man vil herefter kunne læse texten ikke blot som en fremstilling af en mytestruktur, men som en generel demonstration af negationen i stadig ekspanderet form.

Problemet er nu at bestemme transcendensens tematik, og her er renhedsmetaforikken af afgørende betydning. På samme mảde den kulturelle struktur blev båret af lovens højeste repræsentant, præsten, må renhedens bærer kunne bestemmes. Da præsten kvalificeres som fader og avler er det nærliggende at undersøge, hvorledes moderaktanten kan placeres i texten. Det bemærkelsesværdige er at denne kategori ikke manifesteres explicit på aktørplan, men i incestrelationen bliver moderen bærer af det renheds/urørlighedsparadigme, som kendetegner ørneriget: exteroceptivt som renhed og urørlighed, interoceptivt som urenhed og "områdethed". Som aktør/subjekt får hunørnen dermed en dobbelt funktion, idet hun foruden at betegne den kulturelt positive sexualitet samtidig manifesterer incesten (jvf. i denne forbindelse fremhævelsen af den hvide bryst). Hun făr altså netop den funktion som subjektet bestemtes $\mathrm{i} \mathrm{i}$ drømmetydningen: figuren påpeger de forskellige prædikative komplekser i texten uden at blive identificeret med dem. Ved at blive knyttet til samme "subjektivering" forbindes de to paradigmer samtidig $i$ en forløbsmæssig kontinuitet, hvori den transcenderende negation placeres: incesten er den grænse hvor den ekspanderende negation standser.

Negationsforløbet kan nu samles $\mathrm{i}$ en sexualtematik. Præstegården svarer til en oral sexualitet, værditermen er her primært knyttet til indtagelsen af føde. Fjernelsen af faderen, lovens og af kaldets aktant, muliggør ekspansionen $\mathrm{i}$ form af restriktivitetens negation. Flyveturen med hunørnen ind over fjeldene koresponderer med en genital sexualitet (jvf. den groteske samlejeparodi: Klavs beskrives som ængstelig, gumpetung og stakåndet), og man kunne derfor søge efter en fallisk fase og mảske finde den $\mathrm{i}$ begyndelsen af flyveturen, hvor Klavs i en triumferende bevægelse rejser sig fra ladetaget. Flyveturen bliver herved på klassisk vis en stadig ekspanderende erektion der standser foran det hvide moderskød. Det omstyrtede babelstårn er en typisk drømmemetafor. I sin bibelsk-mytologiske sammenhæng henviser det til kulturens sammenbrud, her svarende til incestens destruktive funktion (Incestforbudet er jo ifølge Freud det lovindgreb der differerer det kulturelle univers). Hermed bliver overskridelsens transcendente karakter samtidig forståelig, for på grænsen til ørneriget trues ikke blot den specifikke myteudformning, men muligheden for overhovedet at angive praxis i en lovmæssig betydningssammerhæng. Metaforen peger samtidig på incestens fortrængning i ekstrem form ved det omstyrtede tårn som kastrationen, og kastrationsfunktionen gentages ved Klavs' hjemkomst, hvor faderens suveræne fallos ejakulerer mod himlen og henter den flyvske fallos ned. Ned i møddingpølen og analiteten, den 
sexualitet der i psykoanalysen økonomisk ytrer sig som_penge-værdiophobning.

Forholdet mellem myte, textualitet og betydningsform kan præciseres: idet den sexuelle tematik investeres i mytens form, betegner forløbet fra den orale til den genitale fase en positiv medierende initiationsmyte, hvor individet integreres $\mathrm{i}$ kollektivet $\mathrm{i}$ et ligestillet dominansforhold. Men denne positive myte kan kun opretholdes ved modertermens negation, $\mathrm{i}$ samme øjeblik texten ekspanderer den primære negation og peger på den incestuose praxis (d.v.s. den ikke medierende natur som værdikategoriens ikke-forudsættende form) lukker forløbet med den ikke-individuelt værdiintegrerende lov (den ikke-medierede kultur), der som voldelighed negerer incesten og frelser kulturen (Moderens fravær i den orale fase må forstås som et led $\mathrm{i}$ textens generelle fortrængning af incesten). Men inden da når texten at henvise til en mulig betydningsform, der hverken er myten eller dennes ophævelse eller omvending etc., men muligvis betydningens fragmentation. En mytisk opskrivning af textforløbet kan afslutte denne analyse:

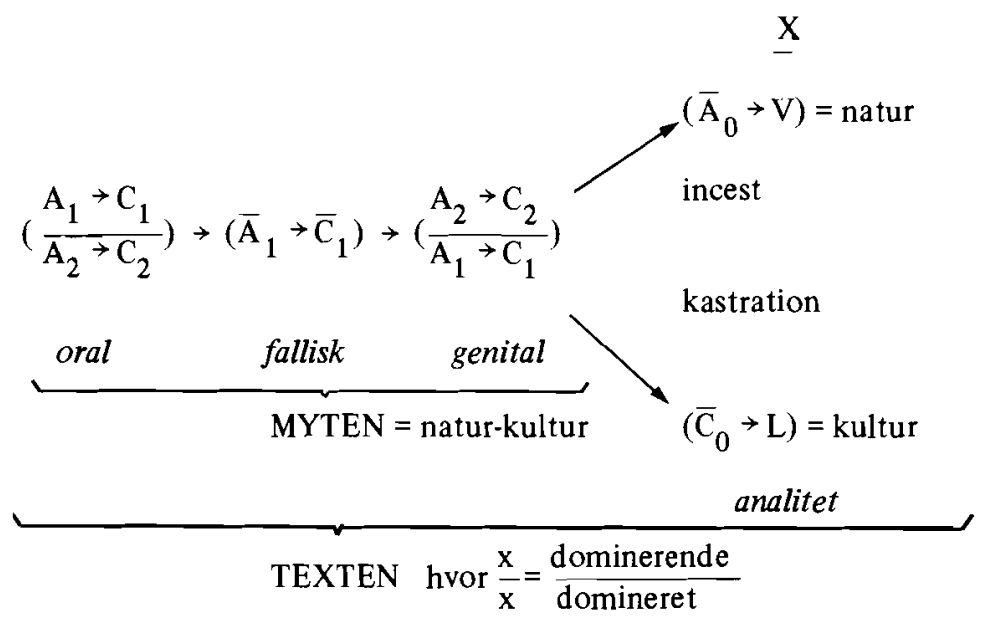

Viggo Røder 